\title{
KAJIAN BANJIR BANDANG DI DESA SUKOLILO MELALUI TINJAUAN PETA SUNGAI
}

\section{STUDY OF FLASH FLOODS IN THE SUKOLILO SUB DISTRICT BY REVIEWING THE MAP OF RIVER}

\author{
Hermain Teguh Prayitno \\ Badan Perencanaan Pembangunan Daerah Kabupaten Pati \\ Email : hermainteguh70@Gmail.com
}

\begin{abstract}
Flash floods often occur in the Sukolilo sub district, Pati Regency Central Java, in particular at Sukolilo village. The high intensity of rainfall in the Sukolilo's catchment area producing high water volume and flow leads to flash floods in the Sukolilo village one hour after the rainfall. It is an interesting phenomenon because the river located in the Sukolilo village experiences flash flood more frequent compared to other rivers in Sukolilo sub district. This research was conducted by comparing rivers in the Sukolilo sub district through quantitative descriptive method with secondary data. The result of this study showed that the morphology of Sukolilo River has the highest catchment area 300 meter above sea level (ASL) and has narrow downstream 20 ASL. According to the calculation, 3 rivers in the Sukolilo sub district has the potential to experience flash flood that are river located in Sukolilo Village, river located in Wegil Village and river located in the border of of Baleadi Village and Kedung Winong Village, consecutively.
\end{abstract}

Keywords: flash floods, river morphology, google maps.

\section{ABSTRAK}

Banjir bandang di Kecamatan Sukolilo Kabupaten Pati Jawa Tengah sering terjadi terutama di Desa Sukolilo. Debit air yang besar serta kecepatan aliran yang tinggi menyebabkan sungai meluap dan mengkhawatirkan warga yang tinggal di sekitar sungai. Hal tersebut disebabkan intensitas hujan yang sangat tinggi di daerah tangkap sungai Sukolilo yang turun satu jam sebelumnya. Kondisi banjir bandang ini menjadi fenomena tersendiri dikarenakan hanya sungai Sukolilo yang sering terjadi. Maka penelitian ini perlu dilakukan dengan cara membuat studi perbandingan sungai-sungai di wilayah Kecamatan Sukolilo melalui metode deskriptif kuantitatif dengan data sekunder. Hasil penelitian menunjukkan bentuk morfologi sungai Sukolilo memiliki daerah tangkap tertinggi 300 meter di atas permukaan laut (DPL) terluas dari sungai sekitarnya dan mengecil di daerah hilir 20 meter DPL. Urutan tertinggi dari rata-rata skor potensi bandang pertama yaitu Sungai Desa Sukolilo, kedua sungai Desa Wegil, dan ketiga sungai perbatasan antara Desa Baleadi dan Desa KedungWinong.

Kata kunci : banjir bandang, morfologi sungai, google maps. 


\section{PENDAHULUAN}

Bencana banjir bandang di Desa Sukolilo Kecamatan Sukolilo Kabupaten Pati pada tanggal 14 Nopember 2016 disebabkan oleh intensitas hujan yang sangat tinggi di daerah tangkap Sungai Sukolilo. Berdasarkan informasi dari beberapa informan di lingkungan masyarakat Sukolilo bahwa waktu perjalanan aliran sungai satu jam setelah hujan turun, besar dan kecilnya debit dan kecepatannya tergantung kondisi hujan. Pada kasus tanggal 14 Nopember 2016 tersebut terjadi bandang selama satu jam setelah turun hujan selama satujam di daerah tangkap. Banjir bandang dan banjir genangan sering terjadi di wilayah Kabupaten Pati akan tetapi belum ada kesadaran masyarakat untuk tanggap bahwa kejadian ini disebabkan adanya kerusakan ekosistem lingkungan di daerah tangkap, dalam hal ini di wilayah pegunungan Kendeng selatan dan pegunungan Muria timur. Khusus sub DAS Sani di pegunungan Muria Timur dalam penelitian Wijayanti (2011), bahwa tingkat bahaya erosi (TBE) di sub DAS Sani DAS Juwana memerlukan tindakan konservasi sebesar 4.425,92 $\mathrm{Ha}$ $(17,42 \%)$. Kejadian banjir di Kabupaten Pati dikarenakan Pati memiliki sungai dengan topografi yang rendah membujur dari wilayah Kabupaten Kudus sampai ke Kecamatan Juwana. Kebiasaan banjir yang terjadi harus diikuti kesadran masyarakat sehingga meminimalisir jatuhnya korban bencana. Artinya, masyarakat sadar dan selalu siap di musim penghujan agar mampu beradaptasi dengan bencana tanpa menjadi korban dan masih mampu beraktivitas seperti biasanya.

Permasalahannya adalah Sungai Sukolilo selalu mengalami banjir bandang dibandingkan dengan sungaisungai lainnya di Kecamatan Sukolilo. Tujuan penelitian adalah untuk sungai dengan potensi bandang terbesar di Kecamatan Sukolilo.

\section{TINJAUAN PUSTAKA}

\section{Bencana Banjir}

Bencana adalah peristiwa atau rangkaian peristiwa yang mengancam dan mengganggu kehidupan dan penghidupan masyarakat yang disebabkan, baik oleh faktor alam dan/atau faktor non alam maupun faktor manusia sehingga mengakibatkan timbulnya korban jiwa manusia, kerusakan lingkungan, kerugian harta benda, dan dampak psikologis (UU Nomor 24 Tahun 2007). Kemudian "Banjir" adalah debit aliran air sungai dalam jumlah yang tinggi, atau debit aliran air di sungai secara relatif lebih besar dari kondisi normal akibat hujan yang turun di hulu atau di suatu tempat tertentu terjadi secara terus menerus, sehingga air tersebut tidak dapat ditampung oleh alur sungai yang ada, maka air melimpah keluar dan menggenangi daerah sekitarnya (Peraturan Dirjen RLPS No.04 thn 2009).

\section{Banjir Bandang}

Banjir bandang adalah banjir yang terjadi secara tiba-tiba dan berlangsung dengan dahsyat. Banjir bandang terbentuk beberapa waktu setelah hujan 
lebat (dalam kisaran waktu beberapa menit sampai beberapa jam) yang terjadi dalam waktu singkat di sebagian daerah aliran sungai (DAS) atau alur sungai yang sempit di bagian hulu. Alur sungai ini memiliki waktu konsentrasi (waktu tiba banjir) yang singkat, sehingga aliran permukaan cepat terkumpul di alur sungai. Karakteristik banjir bandang antara lain yaitu memiliki debit puncak yang melonjak dengan tiba-tiba dan menyurut kembali dengan cepat; Memiliki volume dan kecepatan aliran yang besar; Memiliki kapasitas perpindahan aliran dan daya erosi yang sangat besar sehingga dapat membawa material hasil erosi (kaki tebing, dasar alur sungai, bahan rombakan bendungan alam) menuju hilir; Aliran yang membawa material debris dapat menimbulkan bencana sedimen di daerah hilir setelah titik apex. Penyebab terjadinya banjir bandang adalah terkumpulnya curah hujan lebat yang jatuh dalam durasi waktu yang singkat pada (sebagian) DAS alur hulu sungai, dimana kemudian volume air terkumpul dalam waktu cepat ke alur sungai sehingga menimbulkan lonjakan debit yang besar dan mendadak melebihi kapasitas aliran alur hilirnya; Runtuhnya bendungan, tanggul banjir atau bendungan alam yang terjadi karena tertimbunnya material longsoran pada alur sungai. Dua kriteria dalam penentuan tahapan banjir bandang berdasarkan jenis wilayah, yaitu 1).
Wilayah vulkanis, dimana area rawan banjir bandang terjadi pada sungai yang memiliki kisaran kemiringan $2^{0}$ sampai dengan $3^{0} ; 2$ ). Wilayah non-vulkanis, dimana area rawan banjir bandang terjadi pada sungai yang memiliki kisaran kemiringan $3^{\mathrm{O}}$ sampai dengan $10^{\mathrm{O}}$ (Kementrian Pekerjaan Umum, 2012).

\section{Faktor Penyebab Banjir}

Menurut Kodoatie dan Sugiyanto (2002), faktor penyebab terjadinya banjir dapat diklasifikasikan dalam dua kategori yaitu: (1) penyebab banjir alami dan (2) penyebab banjir akibat tindakan manusia. Banjir akibat alami dipengaruhi oleh curah hujan, fisiografi, erosi dan sedimentasi, kapasitas sungai, kapasitas drainase dan pengaruh air pasang. Sedangkan banjir akibat aktivitas manusia disebabkan karena ulah manusia yang menyebabkan perubahan-perubahan lingkungan seperti : perubahan kondisi Daerah Aliran Sungai (DAS), kawasan pemukiman di sekitar bantaran, rusaknya drainase lahan, kerusakan bangunan pengendali banjir, rusaknya hutan (vegetasi alami), dan perencanaan sistim pengendali banjir yang tidak tepat.

\section{METODE PENELITIAN}

Penelitian ini menggunakan metode deskriptif kuantitatif. Lokasi penelitian berada di Kecamatan Sukolilo yang berada wilayah Pegunungan Kendeng Selatan. Lokasi penelitian disajikan pada Gambar 1. 


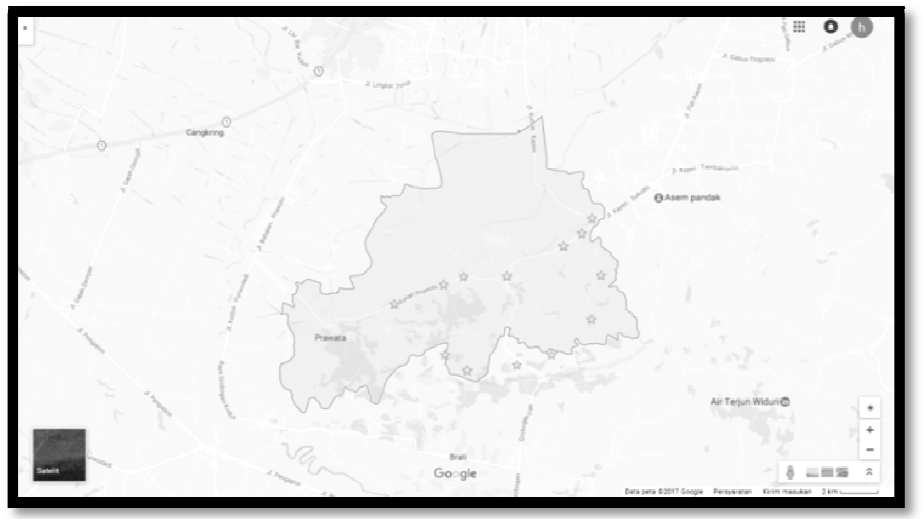

Gambar 1.

Kecamatan Sukolilo Kabupaten Pati

Sumber : Google Maps (2017)

Penelitian dilaksanakan pada bulan Oktober 2016 sampai Februari 2017. Sumber data menggunakan data sekunder berupa data ruster yang diperoleh dari Google Earth, Google Maps, data curah hujan Badan Meteorologi dan Geofisika (BMKG), dan data kejadian banjir dari BPBD Kabupaten Pati. Metode perolehan data dilakukan melalui pengukuran panjang dan luas pada peta dan pencatatan elevasi dan garis kontur pada menu medan Google Maps. Variabel penelitian meliputi luas poligon, panjang sungai, slope sungai, dan lebar jarak antar sungai di dalam satuan sungai setiap kontur ketinggian lokasi. Asumsi penelitian yaitu banjir bandang dapat terjadi jika curah hujan yang jatuh pada luasan dataran pegunungan yang memiliki kemiringan, dengan jarak tertentu menghasilkan aliran deras dalam kesatuan anak sungai menuju sungai utama.

Tahapan perolehan data yaitu (1) Penentuan sub lokasi penelitian dengan melihat foto-foto jembatan pada Google Maps di wilayah Sukolilo pada jalur jalan dari kecamatan Kayen-Sukolilo-Prawoto. Beberapa jembatan terbesar dipilih untuk memberikan informasi bahwa besarnya jembatan mampu menggambarkan besarnya debit sungai di bawahnya. (2) Mengaktifkan fitur kontur pada peta sehingga dapat memperlihatkan ketinggian jalur sungai dari ketinggian terendah sampai dengan tertinggi di Kecamatan Sukolilo. (3) Pengukuran jarak sungai dari Digital Elevation Model (DEM) 20 sampai DEM tertinggi jalur sungai pengamatan. (4) Pengukuran jarak antar cabang terluar anak-anak sungai pada jalur sungai dalam kontur yang sama, dan dilakukan disemua kontur setiap kelipatan 20 meter. (5) Pengukuran luas poligon (lima titik) terluar jalur sungai sehingga mampu mewakili bentuk dan luasan Daerah Aliran Sungai (DAS). (6) Pengamatan ke lima tahapan sebelumnya selalu disertai dengan pembukaan aplikasi Google Earth untuk memastikan apakah jalur sungai di Google Maps sudah mendekati kebenaran pada rona sungai di Google Earth. 
Tahapan perhitungan (1) Nilai lebar antara anak sungai terluar pada satu kontur diurutkan dan dikalikan bobot dari nilai 1 untuk kontur 20 meter dan nilai 10 untuk kontur 340 meter. Kumpulan nilai kualitas potensi lebar daerah anak sungai disederhanakan melalui pembagian kualitas potensi terbesar dengan terkecil, untuk menjadi faktor pembagi yang hasil pembagian terkecil bernilai 1 (satu). (2) Pengurangan nilai kontur tertinggi dengan nilai kontur terendah pada satu jalur sungai dibagi dengan lebar sungai terpendek hingga terpanjang menjadi data kualitas slope (kemiringan sungai rata-rata). (3) Nilai pengukuran luas poligon setiap sungai dibagi dengan hasil pengukuran luas poligon sungai terkecil, menjadi nilai terendah sampai tertinggi untuk disandingkan dengan data curah hujan. (4) Penjumlahan data sungai : lebar sungai terpanjang dibagian hulu, kualitas potensi, panjang sungai, slope, dan luas poligon menjadi nilai kualitas potensi bandang.

Sudut kemiringan sungai untuk wilayah pegunungan vulkanik kemiringan $2^{0}$ sampai dengan $3^{0}$. Wilayah non-vulkanis, yang mana wilayah rawan banjir bandang terjadi pada sungai yang memiliki kisaran kemiringan $3^{0}$ sampai dengan $10^{\circ}$. Sudut kemiringan didapatkan dengan cara pembagian ketinggian dengan panjang sungai menghasilkan persentase kemiringan, kemudian diubah dengan mengkalikan $45^{\circ}$ menjadi sudut kemiringan sungai.

Metode scoring dilakukan dengan pemberian skor atau nilai terhadap masing-masing nilai parameter untuk menentukan tingkat kemampuannya. Penilaian ini berdasarkan keriteria yang telah ditentukan, sedangkan metode pembobotan dilakukan apabila setiap karakter memiliki peranan berbeda atau jika memiliki beberapa parameter untuk menentukan kemampuan lahan atau sejenisnya.

\section{HASIL DAN PEMBAHASAN}

\section{Morfologi Sungai-sungai di Sukolilo}

Lokasi sungai pengamatan berdasarkan besarnya kondisi fisik jembatan dari hasil pencarian Google Maps jalur Kayen-Sukolilo-Prawoto yaitu di Desa Wegil, Baleadi, Kedungwinong, Sukolilo, dan Kedumulyo. Salah satu jembatan yaitu Jembatan Sukolilo seperti terlihat pada Gambar 2. 


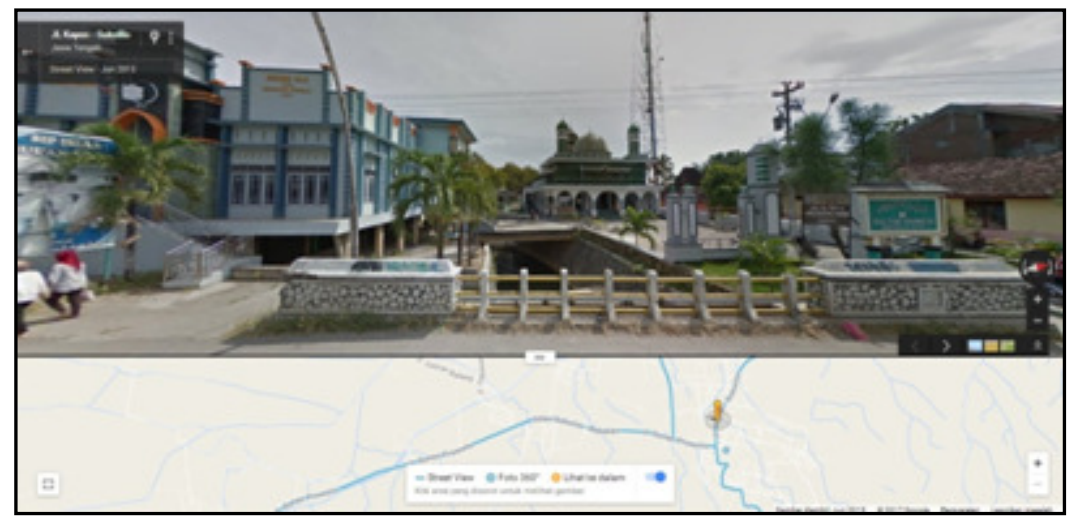

Gambar 2.

Jembatan Sungai di Desa Sukolilo

Sumber : Google Maps (2017)

Lokasi sungai dan anak sungai bersumber dari data Google Maps : (1) Lokasi pertama dari barat sungai di Desa Wegil berada dikoordinat -6.949270; 110.859879 memiliki jaringan anak sungai mulai dari DEM 20 di Desa Wegil sampai DEM 180 di Desa Pakem dan DEM 200 di Desa Kuwawur Desa Tegalsumur Brati dan DEM 300 di Desa sungai Porang Paring Sukolilo. (2) Lokasi kedua sungai di Desa Baleadi barat berada dikoordinat -6.940855 ; 110.879159 memiliki jaringan anak sungai mulai DEM 20 di Desa Baleadi sendiri sampai DEM 180 dan DEM 200 berada di desa Kedungwinong dan Kuwawur terakhir di DEM 220 di Desa Tegalsumur Brati Grobogan. (3) Lokasi ketiga sungai di Desa Baleadi Kedungwinong berada dikoordinat 6.935024; 110.892271 memiliki jaringan anak sungai mulai DEM 20 di Desa Baleadi, Desa Porang Paring, Desa Sumber Jatipohon Kecamatan Grobogan Kabupaten Grobogan. (4) Lokasi keempat sungai di Desa Sukolilo berada dikoordinat $\quad-6.923543 ; \quad 110.917024$ memiliki jaringan anak sungai mulai dari DEM 20 di Desa Sukolilo, Desa Sumbersoko, Desa Sumber Jatipohon Kecamatan Grobogan Kabupaten Grobogan, dan terakhir di Desa Tompegunung. (5) Lokasi kelima sungai di Desa Kedumulyo barat dikoordinat 6.920972, 110.942467 memiliki anak sungai dari DEM 20 di Desa Kedumulyo sendiri disusul Desa Tompegunung, Desa Sumbersoko. (6) Lokasi keenam sungai di Desa Kedumulyo tengah dikoordinat 6.918988; 110.950486 memiliki anak sungai dari DEM 20 di Desa Kedumulyo sendiri disusul Desa Tompegunung. (7) Lokasi terakhir ketujuh yaitu sungai di Desa Kedumulyo timur dengan koordinat $\quad-6.920481, \quad 110.959186$ memiliki anak sungai dari DEM 20 sampai DEM 220 di Desa Kedumulyo sendiri. Pengukuran panjang sungai Sukolilo dari DEM 20 meter hingga DEM 340, panjang DEM 20 s/d 100 s/d 200 s/d 300 dapat dilihat pada Gambar 3. 

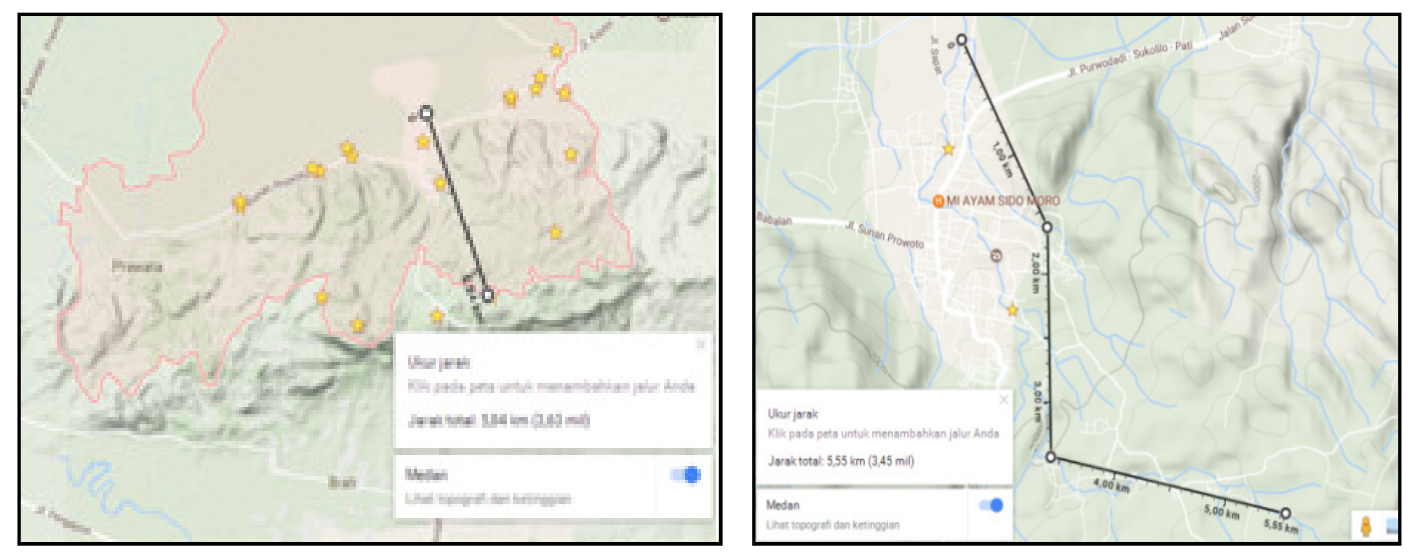

Gambar 3.

Pengukuran Panjang Sungai DEM 20-300 dan 20-100, 100-200, 200-300 Sumber : Pengolahan Data (2017)

Pengukuran panjang sungai dari titik terendah penelitian yaitu DEM 20 meter untuk sungai Sukolilo berada di Desa Sukolilo dan titik tertinggi DEM 320 meter di Desa Tompegunung sepanjang 5.840 meter. Slope sungai yang diukur adalah setiap 100 meter dan terendah 80 yaitu dari DEM 20 sampai dengan 100 sampai dengan 200 sampai dengan 300 disajikan pada Tabel 1 .

Jarak antara anak sungai dan anak sungai terluar pada satu jaringan sungai dan luas kontur (DEM) dapat dilihat pada Gambar 4. Panjang jarak anak sungai ini dikalikan bobot DEM menjadi data kontribusi potensi kecepatan aliran dari daerah hulu menuju daerah hilir. Nilai jarak antar anak sungai di dalam satu sungai pada lokasi setiap DEM di ketujuh sungai beserta pembobotan ditampilkan dalam Tabel 2.
Untuk estimasi luasan jaringan daerah aliran sungai (DAS) digunakan poligon, dengan demikian diperoleh 7 Poligon sungai. Luas Poligon sebagai berikut (1) Sungai paling barat di desa Wegil memiliki luas Poligon $11.17 \mathrm{Km}^{2}$;

(2) Sungai Baleadi barat meliliki luas Poligon $2.90 \mathrm{Km}^{2}$; (3) Sungai Baleadi Keduwinong meliliki luas Poligon 8.32 $\mathrm{Km}^{2}$; (4) Sungai Sukolilo meliliki luas Poligon 12.55 Km2; (5) Sungai Baleadi Kedumulyo barat meliliki luas poligon $2.87 \mathrm{Km}^{2}$; (6) Sungai Kedumulyo tengah meliliki luas Poligon $2.46 \mathrm{Km}^{2}$; (7) Sungai Kedumulyo timur meliliki luas Poligon $1.19 \mathrm{Km}^{2}$. Skor luas Poligon berdasarkan luas masing-masing sungai dibagi dengan luas 19 poligon sungai terkecil. Nilai skor untuk luas Poligon ditampilkan dalam Tabel 2. 
Tabel 1.

Hasil Penguluran Kemiringan Sungai

\begin{tabular}{lccrrrr}
\hline \multirow{2}{*}{$\begin{array}{c}\text { Desa } \\
\text { Sungai titik Pantau }\end{array}$} & \multicolumn{3}{c}{ Kemiringan ( Slope )\% } & Jumlah & rata2 & $\begin{array}{c}\text { Skor } \\
\text { = 6/terkecil }\end{array}$ \\
\cline { 2 - 5 } & 20 s/d 100 & 100 s/d 200 & 200 s/d 300 & & & 1,0 \\
\hline Wegil & 0,081 & 0,071 & 0,035 & 0,188 & 0,063 & 1,4 \\
Baleadi Barat & 0,125 & 0,052 & 0,088 & 0,265 & 0,088 & 1,1 \\
Baleadi-Kd Winong & 0,065 & 0,095 & 0,047 & 0,207 & 0,069 & 1,3 \\
Sukolilo & 0,088 & 0,055 & 0,107 & 0,250 & 0,083 & 1,4 \\
Kedumulyo Barat & 0,107 & 0,094 & 0,068 & 0,269 & 0,090 & 1,5 \\
Kedumulyo Tengah & 0,061 & 0,098 & 0,128 & 0,287 & 0,096 & 2,2 \\
Kedumulyo Timur & 0,077 & 0,196 & & 0,273 & 0,136 & \\
& 0,086 & 0,095 & 0,079 & & & \\
\hline
\end{tabular}

Sumber : Pengolahan Data (2017)

Tabel 2.

Skor Jarak Anak-anak Sungai

\begin{tabular}{|c|c|c|c|c|c|c|c|c|}
\hline \multicolumn{9}{|c|}{ JARAK ANAK SUNGAI X BOBOT DEM ( meter ) } \\
\hline \multirow{2}{*}{$\begin{array}{l}\text { DEM } \\
\text { meter }\end{array}$} & \multirow{2}{*}{ ВОВОТ } & \multirow{2}{*}{ Wegil } & \multicolumn{2}{|c|}{ Baleadi } & \multirow{2}{*}{ Sukolilo } & \multicolumn{3}{|c|}{ Kedumulyo } \\
\hline & & & barat & Kdwinong & & barat & tengah & timur \\
\hline 20 & 0,588 & 98,24 & 186,47 & 0,59 & 78,26 & 0,59 & 0,59 & 0,59 \\
\hline 40 & 1,176 & 609,4 & 735,29 & 401,18 & 238,82 & 1,18 & 390,59 & 660,00 \\
\hline 60 & 1,765 & $1.336,0$ & $1.205,30$ & 697,06 & $1.005,90$ & 1,77 & 764,12 & $1.817,60$ \\
\hline 80 & 2,353 & $2.155,0$ & $1.661,20$ & $1.287,10$ & 997,65 & 160,00 & $1.054,10$ & $2.143,50$ \\
\hline 100 & 2,941 & $3.059,0$ & $2.132,40$ & $1.761,80$ & $1.529,40$ & 908,82 & $1.352,90$ & $2.135,30$ \\
\hline 120 & 3,529 & $4.059,0$ & $2.643,50$ & $2.431,80$ & $2.124,70$ & $1.260,00$ & $1.644,70$ & $2.583,50$ \\
\hline 140 & 4,118 & $2.549,0$ & $3.005,90$ & $3.442,40$ & $2.779,40$ & $1.708,80$ & $1.976,50$ & $3.339,40$ \\
\hline 160 & 4,706 & $5.224,0$ & $3.341,20$ & $4.320,00$ & $3.223,50$ & $2.795,30$ & 0,00 & $3.905,90$ \\
\hline 180 & 5,294 & $8.682,0$ & $3.854,10$ & $5.018,80$ & $5.558,80$ & $3.986,50$ & 889,41 & $4.087,10$ \\
\hline 200 & 5,882 & $13.706,0$ & $4.729,40$ & $5.470,60$ & $10.353,00$ & $6.000,00$ & $3.247,10$ & 0,00 \\
\hline 220 & 6,471 & $10.871,0$ & $4.736,50$ & $7.182,40$ & $15.012,00$ & $7.958,80$ & $2.575,30$ & 0,00 \\
\hline 240 & 7,059 & $2.654,0$ & $3.529,40$ & $12.988,00$ & $18.706,00$ & $5.823,50$ & $7.411,80$ & 0,00 \\
\hline 260 & 7,647 & $5.804,0$ & $16.594,00$ & $17.129,00$ & $18.429,00$ & $5.804,10$ & $8.258,80$ & 0,00 \\
\hline 280 & 8,235 & $8.565,0$ & $5.163,50$ & $2.396,50$ & $19.188,00$ & $7.560,00$ & $8.894,10$ & 0,00 \\
\hline 300 & 8,824 & $10.941,0$ & 0,00 & $16.676,00$ & $23.118,00$ & $5.514,70$ & 8,82 & 0,00 \\
\hline 320 & 9,412 & $5.609,0$ & 0,00 & $28.706,00$ & $22.682,00$ & 0,00 & 0,00 & 0,00 \\
\hline \multirow[t]{2}{*}{340} & 10,000 & $7.710,0$ & 0,00 & 0,00 & 0,00 & 0,00 & 0,00 & 0,00 \\
\hline & & $93.631,0$ & $53.518,00$ & $109.910,00$ & $145.025,00$ & $49.484,00$ & $38.469,00$ & $20.673,00$ \\
\hline Skor & & 4,53 & 2,59 & 5,32 & 7,02 & 2,39 & 1,86 & 1,00 \\
\hline
\end{tabular}

Sumber : Pengolahan Data (2017) 

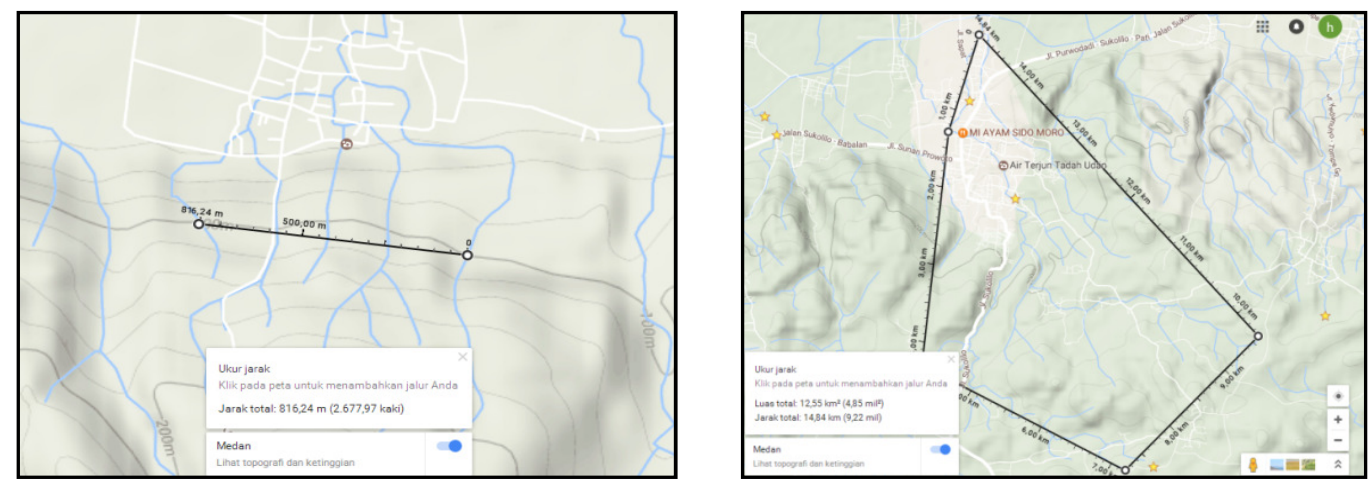

\section{Gambar 4.}

Pengukuran Panjang Sungai dan Luas Poligon

Sumber : Pengolahan Data (2017)

Pembobotan dilakukan untuk mempermudah pembacaan dimana panjang antar sungai menggambar adanya daerah tangkap hujan pada ketinggian kontur yang sama. Semakin tinggi kontur, akan besar berkontribusi dalam mempercepat aliran anak sungai hingga ke sungai utama. Pembobotan dibagi menjadi 10 bobot dari 17 point perbedaan ketinggian. Hasil skor menunjukkan perbedaan kualitas sungai dari perhitungan panjang anak sungai, dikalikan bobot dan penentuan skor. Kondisi sungai di Sukolilo melalui 7 lokasi terbesar digambarkan melalui perolehan rata-rata skor potensi, slope, dan poligon sebagaimana ditampilkan pada Tabel 3 .

Tabel 3.

Skor Rata-rata Sungai-sungai di Sukolilo

\begin{tabular}{lrrrr}
\hline \multirow{2}{*}{ Desa } & \multicolumn{4}{c}{ Skor } \\
\cline { 2 - 5 } Sungai Titik Pantau & Potensi & Slope & Poligon & Rata-rata \\
\hline Wegil & 4,53 & 0,9 & 9,39 & 4,94 \\
Baleadi barat & 2,59 & 1,3 & 2,44 & 2,10 \\
Baleadi kd Winong & 5,32 & 1,0 & 6,99 & 4,44 \\
Sukolilo & 7,02 & 1,2 & 10,55 & 6,26 \\
Kedumulyo barat & 2,39 & 1,3 & 2,41 & 2,04 \\
Kedumulyo tengah & 1,86 & 1,4 & 2,07 & 1,77 \\
Kedumulyo timur & 1,00 & 1,3 & 1,00 & 1,11 \\
\hline \multicolumn{2}{c}{ Sumber : Pengolahan Data (2017) }
\end{tabular}

Kondisi skor potensi, slope poligon disederhanakan melalui skor rata-rata setiap sungai sehingga mendapatkan nilai tertinggi pertama sungai Sukolilo, kedua sungai Wegil, ketiga sungai Baleadi Kedungwinong. Dengan demikian, Sungai Sukolilo sering terjadi banjir bandang dikarenakan 
(1) Luas DAS melalui pendekatan luas poligon dengan skor 6,26 (terluas) yaitu $12.55 \mathrm{Km}^{2}$. (2) Kemiringan rata-rata melalui skor 1,3 yaitu sesuai dengan buku pedoman penanggulangan bencana Kementrian Pekerjaan Umum, 2012 yaitu 3 sampai dengan $10^{\circ}$ maka pendekatan kemiringan dari DEM 20 sampai dengan DEM 300 yaitu 0,088\% $\left(3,96^{\circ}\right) ; 0,055 \%\left(2,47^{\circ}\right) ; 0,107 \%\left(7,65^{\circ}\right)$. (3) Skor potensi yaitu panjang jarak antar anak sungai di DEM yang sama tertinggi memiliki skor 7,02 seperti pada Tabel 3 .

\section{KESIMPULAN DAN SARAN}

\section{Kesimpulan}

Sungai Sukolilo memiliki potensi bandang terbesar di Kecamatan Sukolilo dikarenakan (1) Luas DAS melalui pendekatan luas poligon dengan skor 6,26. (2) Kemiringan rata-rata melalui skor 1,3. (3) Skor potensi yaitu panjang jarak antar anak sungai di DEM yang sama tertinggi memiliki skor 7,02.

\section{Saran}

1. Mempertimbangkan untuk pembuatan sistem peringatan dini kebencanaan, baik didukung oleh peralatan maupun konektivitas masyarakat hulu dan hilir khusus menyikapi potensi banjir bandang.

2. Mempertimbangkan untuk pembuatan dam-dam pengendali banjir, perbaikan jalur sungai dan pembuatan rorak-rorak perkebunan dan pekarangan.

3. Pemberian informasi kepada masyarakat sempadan sungai di daerah hilir tentang daerah yang menjadi tangkapan air hujan menuju sungai tersebut.

\section{DAFTAR PUSTAKA}

Google Maps. (2017). Kecamatan Sukolilo Pati. https://www.google.co.id/maps/pla ce/Sukolilo, +Kabupaten+Pati, +Ja wa+Tengah/@ -

6.931088,110.8214448,12z/data=! $3 \mathrm{ml} ! 4 \mathrm{bl!} 4 \mathrm{~m} 5 ! 3 \mathrm{~m} 4 ! 1 \mathrm{~s} 0 \times 2 \mathrm{e} 70 \mathrm{c} 7 \mathrm{dc}$ d3d7b09f:0x4027a76e352f230!8m 2!3d-6.9344012!4d110.8791343, diakses 28 Februari 2017.

Google Maps. (2017). Foto Sungai Desa Sukolilo Pati. https://www.google.co.id/maps/pla ce/Sukolilo, +Kabupaten+Pati, +Ja wa+Tengah/@ -

$6.931088,110.8214448,12 z / d a t a=!$

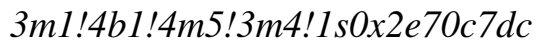
d3d7b09f:0x4027a76e352f230!8m 2!3d-6.9344012!4d110.8791343, diakses 28 Februari 2017.

Kementrian Pekerjaan Umum Republik Indonesia. (2012). Draf akhir : Pedoman Pembuatan Peta Rawan Longsor dan Banjir Bandang Akibat Runtuhnya Bendungan Alam.

https://www.jica.go.jp/project /indonesian

/indonesia/0800040/.../outputs_11 _01.pdf, diakses 23 Februari 2017.

Kodoatie, R. J., Sugiyanto. (2002). Banjir, Beberapa Penyebab dan Pengendaliannya dalam Perspektif Lingkungan. Yogyakarta : Pustaka Pelajar. 
Peraturan Direktur Jenderal Rehabilitasi

Lahan dan Perhutanan Sosial No :

P. 04/V-SET/2009 tentang

Pedoman Monitoring dan

Evaluasi Daerah Aliran Sungai.

Undang-Undang Nomor 24 Tahun 2007

tentang Penanggulangan Bencana.

Wijayanti, R. (2011). Studi Identifikasi

Pengelolaan Lahan Berdasar

Tingkat Bahaya Erosi (TBE)

(Studi Kasus di Sub DAS Sani,

DAS Juwana, Jawa Tengah).
Jurnal Ilmu Lingkungan, Vol. 9(2): 57-61.

\section{BIODATA PENULIS}

Hermain Teguh Prayitno, lahir 11 April 1970 di kota Rembang Jawa Tengah. Magister Ilmu Lingkungan dari Universitas Diponegoro (UNDIP) Semarang tahun 2008. Saat ini bekerja sebagai peneliti pertama di Badan Perencanaan Pembangunan Daerah Kabupaten Pati. 